\title{
ANALISIS KEPUASAN KERJA KARYAWAN DI PT PERKEBUNAN NUSANTARA V KEBUN SEI ROKAN KECAMATAN PAGARANTAPAH DARUSSALAM KABUPATEN ROKAN HULU
}

\author{
Aidil Mansukra ${ }^{1)}$, Eliza $^{2)}$, Suardi Tarumun ${ }^{2)}$ \\ 1) Mahasiswa Jurusan Agribisnis, Fakultas Pertanian, Universitas Riau. \\ 2) Staf pengajar Jurusan Agribisnis, Fakultas Pertanian, Universitas Riau. \\ Jl. HR. Subrantas KM 12,5 Simpang Baru, Pekanbaru 28294 \\ Email:aidilmansukra19@gmail.com
}

\begin{abstract}
ABSTRAK
Penelitian ini bertujuan untuk 1) mengetahui karakteristik karyawan PT. Perkebunan Nusantara V Kebun Sei Rokan Kecamatan Pagarantapah Darussalam Kabupaten Rokan Hulu 2) menganalisis tingkat kepuasan karyawan bekerja di PT. Perkebunan Nusantara V Kecamatan Pagarantapah Darussalam Kabupaten Rokan Hulu penelitian dilaksanakan pada bulan februari 2016. Metode yang digunakan adalah metode survei. Pengambilan sampel dilakukan dengan purposive sampling, dengan kriteria karyawan yang bekerja di afdeling I sampai afdeling $X$ serta karyawan yang bekerja di bagian teknik umum, administrasi dan pimpinan di kebun Sei Rokan. Hasil penelitian menunjukkan bahwa karyawan yang bekerja di PTPNV Kebun Sei Rokan dominan adalah laki-laki 86,66\% dengan rata-rata umur 38 tahun dimana dengan tingkat pendidikan karyawan adalah SMP dan SMA dengan rata-rata $41,11 \%$ dan $26,67 \%$ dan rata rata lama bekerja karyawan adalah 14 tahun, besaran gaji yang diterima < UMP yaitu $72,22 \%$.Analisis tingkat kepuasan kerja karyawan diperolehgaji memiliki skor tingkat kepuasan tertinggi yaitu 4,19 dengan kategori "sangat puas" selanjutnya diikuti dengan tingkat kepuasan terhadap penyelia dengan skor 3,76 kategori "puas" selanjutnya diikuti tingkat kepuasan terhadap teman sekerja skor 3,69 kategori "puas" kemudian kategori promosi yaitu 3,43 dengan kategori "puas" sedangkan skor terendah kategori terhadap pekerjaan itu sendiri yaitu 3,23 kategori "cukup puas" sehingga rata-rata tingkat kepuasan kerja karyawan di PTPNV Kebun Sei Rokan dengan skor 3,66 dengan kategori "puas".
\end{abstract}

Kata Kunci: PT. Perkebunan Nusantara V Kebun Sei Rokan, Faktor kepuasan, Tingkat Kepuasan Karyawan

\section{PENDAHULUAN}

PT. Perkebunan Nusantara V merupakan BUMN perkebunan yang didirikan tanggal 11 Maret 1996. Salah satu PTPN V yang ada di Provinsi Riau adalah PT. Perkebunan Nusantara V Kebun Sei Rokan yang terletak di Desa Pagarantapah Kecamatan Pagarantapah Darussalam Kabupaten Rokan Hulu. PT. Perkebunan Nusantara V KebunSei Rokan merupakan salah satu perusahaan yang bergerak dalam bidang perkebunan kelapa sawit dan dengan luas lahan seluruhnya adalah 10.630,10 ha. Perusahaan dalam mengelola lahan yang luas tersebut

1 I Analisis Kepuasan Kerja Karyawan Di PT Perkebunan Nusantara V Kebun Sei Rokan Kecamatan Pagarantapah Darussalam Kabupaten Rokan Hulu 
tentunya membutuhkan sumber daya manusia untuk menghasilkan produksi bagi perusahaan.Sumber daya manusia yang dimaksud adalah karyawan karena karyawan merupakan penggerak utama jalannya kegiatan dan sebagai penentu tercapainya tujuan perusahaan. Jumlah karyawan di perusahaan ini sebanyak 1.051 orang karyawan yang sudah tergabung dengan karyawan pimpinan.

Usaha peningkatan produksi hasil perkebunan tentunya tidak terlepas dari pemanfaatan sumber daya yang dimiliki perusahaan dengan sebaik-baiknya. Perusahaan dituntut untuk dapat memprioritaskan penanganan terhadap peningkatan kualitas sumber daya yang dimilikinya, antara lain sumber daya manusia. Sumber daya manusia adalah penggerak utama suatu organisasi atau perusahaan. Karyawan yang aktif, inovatif, kreatif, partisipatif dan memiliki loyalitas kepada perusahaan serta mendukung terhadap pencapaian tujuan perusahaan sangat dibutuhkan dalam memperkuat daya saing perusahaan dalam suatu industri yang terus mengalami pertumbuhan. Permasalahan ketenagakerjaan merupakan hal yang sangat penting dalam pengelolaan suatu perkebunan. Para karyawan bekerja di perusahaan untuk menyelesaikan berbagai tugas sesuai posisi atau jabatan mereka. Untuk mencapai tujuan tersebut, para karyawan dituntut memberikan yang terbaik bagi perusahaan. Karyawan yang bekerja dengan baik diharapkan dapat meningkatkan kinerja perusahaan secara keseluruhan, yang pada akhirnya membawa kesejahteraan bersama (Istijanto, 2006).Karyawan merupakan asset perusahaan yang sangat berguna bagi kepentingan manajemen dalam menjalankan operasionalisasi dan aktivitas perusahaan. Karyawan yang mempunyai tingkat keterlibatan pekerjaan yang tinggi sangat memihak dan benarbenar peduli dengan bidang pekerjaan yang mereka lakukan. Karyawan selaku sumber daya manusia harus diperhatiakan dalam berbagai segi karena tanpa kehadiran sumber daya manusia tidak mungkin roda perusahaan berjalan dengan lancar.

Salah satucara yang dilakukan perusahaan adalah dengan memperhatikan dan meningkatkan sumber daya manusia yang ada di perusahaan. Karyawan diharapkan bekerja dengan baik bagi perusahaan agar tercapainya tujuan perusahaan sehingga membawa kesejahteraan dan keuntungan bersama. Karyawan yang bekerja dengan dedikasi yang tinggi dan menyenangi pekerjaanya maka akan merasa puas bekerja dan menganggap pekerjaan itu salah satu hobi 
bagi dirinya. Kepuasan kerja menjadi faktor yang dapat memberikan manfaat bagi kepentingan individu dan perusahaan. Karyawan akan merasa diperhatikan jika mereka puas atas apa yang diberikan perusahaan kepada mereka. Pemberdayaan dan pengelolaan karyawan melalui kondisi lingkungan kerja yang kondusif, komunikasi yang baik, imbalan kerja yang sesuai serta sikap dan perilaku atasan yang akan memunculkan kepuasan bekerja bagi karyawan. Sehingga dapat menumbuhkan sikap loyal terhadap perusahaan dan pada akhirnya akan berdampak kepada kualitas layanan yang akan diberikan oleh karyawan. Adapun tujuan dari penelitian ini adalah 1.Mengetahiu karateristik karyawan PT. Perkebunan Nusantara V Kebun Sei Rokan Kecamatan Pagarantapah Kabupaten Rokan Hulu. 2. Menganalisis tingkat kepuasan karyawan di PT. Perkebunan Nusantara V Kebun Sei Rokan Kecamatan Pagarantapah Kabupaten Rokan Hulu.

\section{METODE PENELITIAN}

\section{Teknik Pengambilan Sampel dan Pengumpulan Data}

Sampel pada penelitian ini adalah karyawan afdeling I sampai afdeling X yang bekerja pada tanaman kelapa sawit dari pimpinan terbawah dan karyawan yang ada di PTPN V Kebun Sei Rokan Kecamatan pagarantapah Darussalam kabupaten rokan hulu. Metode yang dilakukan dalam penelitian ini adalah metode survei. Pengambilan sampel dilakukan secara purposive sampling (sengaja).

Dengan kriteria pengambilan sampel adalah karyawan pelaksana yang bekerja di lapangan dan di kantor Sampel yang akan diambil terdiri dari: Mandor besar, mandor, krani serta seluruh karyawan pelaksana pada tanaman kelapa sawit Jumlah karyawan pelaksana yang bekerja pada tanaman kelapa sawit pada setiap lokasi bagian/afdeling di PT.Perkebunan Nusantara V Kebun Sei Rokan sebanyak 904 orang. Sampel dalam penelitian ini diambil sebanyak $10 \%$ dari 904 karyawan pelaksana yang bekerja pada kelapa sawit, yaitu sebanyak 90 karyawan.

\section{Metode Pengambilan Data}

Data yang dikumpulkan dalam penelitian ini meliputi data primer dan data skunder baik yang bersifat kualitatif maupun kuantitatif. Data primer akan diperoleh dari wawancara secara langsung dengan karyawan perusahaan yang terpilih menjadi sampel dengan menggunakan daftar wawancara yang berisi 
pertanyaan terkait dengan (umur, pendidikan, lama bekerja dan lain-lain). Data sekunder diperoleh dari studi kepustakaan.Data primer yang diperoleh dalam penelitian ini dari arsip perusahaan PTPN V Kebun Sei Rokan, data yang dianggap perlu dan berkaitan dengan penelitian ini serta buku-buku yang memuat teori-teori yang berkaitan dengan penelitian ini.

\section{Metode Analisis Data}

\section{Analisis Deskriptif}

Analisa deskriptif dilakukan untuk mengetahui karakteristik sampel berdasarkanumur, jenis pekerjaan, jenis kelamin, tingkatpendidikan,masa kerja, jumlah anggota keluarga yang bekerja, jumlah tanggungandalam keluarga dengan cara mentabulasi hasil kuisioner secara manual.

\section{Analisis Deskriptif Kualitatif}

Analisa deskriptif kualitatif bertujuan untuk mengetahui bagaimanat ingkat kepuasan kerja karyawan dengan menggunakan alat ukur skala likert. Menurut Sugiyono (2006) Skala Likert digunakan untuk mengukur sikap, pendapat dan persepsi seseorang atau sekelompok tentang kejadian atau gejala sosial.

Tabel 1. Bobot nilai jawaban responden untuk tingkat kepuasan karyawan

\begin{tabular}{lc}
\hline Jawaban & Bobot Nilai \\
\hline Sangat puas & 5 \\
Puas & 4 \\
Cukup puas & 3 \\
Kurang puas & 2 \\
Sangat kurang puas & 1 \\
\hline
\end{tabular}

Tabel 2. Skor tingkat kepuasan karyawan

\begin{tabular}{lc}
\hline \multicolumn{1}{c}{$\begin{array}{c}\text { Skor Tingkat Kepuasan Karyawan } \\
\text { Kategori }\end{array}$} & $\begin{array}{c}\text { Skor } \\
\text { Sangat Puas }\end{array}$ \\
Puas & $4,20-5,00$ \\
Cukup puas & $3,40-4,19$ \\
Kurang puas & $2,60-3,39$ \\
Sangat kurang & $1,80-2,59$ \\
puas & $1,00-1,79$ \\
\hline
\end{tabular}




\section{HASIL DAN PEMBAHASAN}

\section{Karakteristik Karyawan}

\section{Jenis Kelamin}

Karyawan laki-laki lebih banyak dibutuhkan dalam bekerja di lapangan dibandingkan dengan karyawan perempuan.Hal ini terjadi karena jenis pekerjaan yang dilakukan di lapangan lebih membutuhkan tenaga kerja laki-laki dibandingkan dengan perempuan dapat dilihat pada Tabel 3.

Tabel 3. Karakteristik Sampel Berdasarkan Jenis Kelamin

\begin{tabular}{lcc}
\hline $\begin{array}{l}\text { Jenis } \\
\text { Kelamin }\end{array}$ & $\begin{array}{c}\text { Jumlah } \\
\text { (Orang) }\end{array}$ & $\begin{array}{c}\text { Persentase } \\
(\boldsymbol{\%})\end{array}$ \\
\hline Laki-laki & 78 & 86,66 \\
Perempuan & 12 & 13,33 \\
\hline Total & $\mathbf{9 0}$ & $\mathbf{1 0 0}$ \\
\hline
\end{tabular}

Sumber: Data Olahan, 2015

Berdasarkan Tabel 3 diketahui bahwa karyawan perempuan lebih banyak bekerja di bagian pemeliharaan dan bagian kantor yang tugasnya lebih ringan sehingga jumlahnya lebih sedikit yaitu hanya 12 orang dengan persentase $13,33 \%$ sedangkan karyawan laki-laki lebih banyak dibutuhkan dalam bekerja di lapangan khususnya pada bagian panen sehingga jumlahnya lebih banyak yaitu sebesar 78 orang dengan persentase $86,66 \%$.

\section{Umur}

Menurut peneliti, umur merupakan salah satu faktor yang ada dari dalam diri seseorang untuk mencapai kepuasan dalam bekerja.Alasannya karena, dengan umur yang sudah semakin tua maka kondisi fisik seseorang semakin lemah dan begitu juga sebaliknya sehingga menimbulkan kepuasan tersendiri dari seseorang dalam melakukan pekerjaan. Dimana pada umur yang sangat muda dan yang baru memulai mencari pengalaman untuk bekerja, juga mempunyai semangat untuk bekerja keras,diharapkan dengan banyak karyawan yang berjiwa muda ini dapat kegiatan produksi mendapatkan hasil yang baik dan memuaskan sehingga dapat membuat majunya produktivitas. 
Tabel 4. Karakteristik Sampel Berdasarkan Umur.

\begin{tabular}{ccc}
\hline $\begin{array}{c}\text { Umur } \\
\text { (tahun) }\end{array}$ & $\begin{array}{c}\text { Jumlah } \\
\text { (Orang) }\end{array}$ & $\begin{array}{c}\text { Persentase } \\
(\boldsymbol{\%})\end{array}$ \\
\hline $25-36$ & 39 & 43,33 \\
$37-43$ & 33 & 36,67 \\
$44-50$ & 15 & 16,66 \\
$>50$ & 3 & 3,33 \\
Total & $\mathbf{9 0}$ & $\mathbf{1 0 0}$ \\
\hline
\end{tabular}

Rata-rata 38tahun

Sumber: Data olahan, 2015

Tabel 4 menerangkan bahwa dari 90 sampel diketahui distribusi umur karyawan di PT. Perkebunan Nusantara V Kebun Sei Rokan paling banyak berumur antara 25 - 36 tahun yaitu 39 orang (43,33\%) dan selanjutnya karyawan yang berumur $>50$ tahun hanya berjumlah 3 orang $(3,33 \%)$. Rata-rata umur dari karyawan yang bekerja di lapangan pada tanaman kelapa sawit adalah berada pada umur 38 tahun yang artinya bahwa rata-rata umur karyawan yang bekerja di Kebun Sei Rokan masih produktif sehingga kemampuan fisiknya lebih kuat dibandingkan dengan kondisi fisik karyawan yang sudah lanjut usia.

\section{Tingkat Pendidikan}

Tingkat pendidikan karyawan memberikan pengaruh besar dalam meningkatkan kepuasan karyawan dalam bekerja karena pendidikan merupakan salah satu faktor internal dalam diri karyawan.

Tabel 5. Karakteristik Sampel Berdasarkan Tingkat Pendidikan

\begin{tabular}{lcc}
\hline $\begin{array}{l}\text { Tingkat } \\
\text { Pendidikan }\end{array}$ & $\begin{array}{c}\text { Jumlah } \\
\text { (orang) }\end{array}$ & $\begin{array}{c}\text { Persentase } \\
(\boldsymbol{\%})\end{array}$ \\
\hline SD & 15 & 16,67 \\
SMP & 37 & 41,11 \\
SMA & 24 & 26,67 \\
PT & 14 & 15,56 \\
\hline Total & $\mathbf{9 0}$ & $\mathbf{1 0 0}$
\end{tabular}

Sumber: Data Olahan, 2015

Tabel 5 dapat diketahui bahwa tingkat pendidikan karyawan dengan jumlah terbanyak berada pada lulusan SMP berjumlah 37 orang $(41,11 \%)$, lulusan SMA berjumlah 24 orang $(26,67 \%)$, karyawan dengan tingkat pendidikan SD berjumlah 15 orang $(16,67 \%)$ dan tingkat pendidikan lulusan dari PT memiliki jumlah terkecil yaitu hanya berjumlah 14 orang $(15,56 \%)$. Karyawan yang berpendidikan rendah maupun tinggi dinyatakan bias naik golongan maupun 
naik jabatan melalui penilaian prestasi kerja karyawan $(\mathrm{P} 2 \mathrm{~K})$ yang dilakukan perusahaan. Penilaian prestasi kerja karyawan dilakukan dalam setahun sekali berupa kenaikan golongan kecuali untuk karyawan yang memiliki prestasi kerja luar biasa maka dapat dilakukan dua kali dalam setahun.

\section{Lama Bekerja}

Lamanya masa kerja bagi karyawan akan menunjukkan tingkat kemampuan dan pengalaman yang dmiliki oleh karyawan. Pengalaman bekerja akan menunjukkan tingkat kepuasan yang dimiliki oleh seseorang terhadap pekerjaanya. Dalam perusahaan ini, lama bekerja karyawan dihitung sejak karyawan diangkat menjadi karyawan tetap di perusahaan.

Tabel 6.Karakteristik Sampel Berdasarkan Lama Bekerja

\begin{tabular}{ccc}
\hline $\begin{array}{c}\text { Lama Bekerja } \\
\text { (Tahun) }\end{array}$ & $\begin{array}{c}\text { Jumlah } \\
\text { (orang) }\end{array}$ & $\begin{array}{c}\text { Persentase } \\
(\%)\end{array}$ \\
\hline $4-10$ & 22 & 24,44 \\
$11-17$ & 46 & 51,11 \\
$18-24$ & 15 & 16,67 \\
$>24$ & 7 & 7,78 \\
\hline Total & $\mathbf{9 0}$ & $\mathbf{1 0 0}$ \\
\hline
\end{tabular}

Rata-rata $\quad 14$

Sumber: Data Olahan, 2015

Tabel 6 menerangkan bahwa lama bekerja karyawan di PT Perkebunan Nusantara V Kebun Sei Kencana yaitu lama bekerja tertinggi dan termuda berada pada lama bekerja antara 11 - 17 tahun dengan jumlah karyawan sebanyak 46 orang $(51,11 \%)$ lama bekerja yang dimaksud dalam penelitian ini adalah masa kerja karyawan. Karyawan yang lama bekerjanya antara <24tahun memiliki jumlah terendahdalam sampel penelitian yaitu 7 orang $(7,77 \%)$ sedangkan lama bekerja 4-10 tahun memiliki jumlah lebih sedikit yaitu 22 orang $(24,44 \%)$.

\section{Gaji}

Gaji merupakan imbalan jasa yang diharapkan oleh karyawan atas tanggung jawab pekerjaan yang mereka lakukan.Apabila gaji sudah cukup bagi karyawan maka secara otomatis tercipta kepuasan kerja bagi diri karyawan. 
Tabel 7. Karakteristik Sampel Berdasarkan Gaji

\begin{tabular}{ccc}
\hline $\begin{array}{c}\text { Gaji } \\
(\mathbf{R p})\end{array}$ & $\begin{array}{c}\text { Jumlah } \\
\text { (orang) }\end{array}$ & $\begin{array}{c}\text { Persentase } \\
(\mathbf{\%})\end{array}$ \\
\hline <UMP & 25 & 27,78 \\
>UMP & 65 & 72,22 \\
\hline Total & $\mathbf{9 0}$ & $\mathbf{1 0 0}$ \\
\hline \multicolumn{2}{l}{ Sumber: Data Olahan, 2015} &
\end{tabular}

Pada tabel 7 dapat disimpulkan bahwa gaji yang diterima karyawan berdasarkan golongan yang telah ditetapkan perusahaan berdasarkan jabatan.Golongan yang ada di PTPNV Sei Rokan mulai dari golongan IA/00 sampai IV/06.Gaji yang dimaksud dalam penelitian ini merupakan gaji bersih yang diterima karyawan karena sudah dipotong dengan kewajiban-kewajiban yang harus ditanggung karyawan.Jadwal pembayaran gaji kepada karyawan setiap bulannya dilaksanakan sesuai jadwal dan system pembayarannya diatur sesuai ketentuan yang berlaku.

\section{Tingkat Kepuasan Karyawan}

Kepuasan kerja merupakan sikap emosional yang dimiliki oleh seseorang dalam menyenangkan dan mencintai pekerjaannya (Hasibuan, 2009).Bagi karyawan kepuasan dan ketidakpuasan secaraindividual berasal dari perbandingan antara apa yangditerima karyawan dari pekerjaan yang dilakukandengan apa yang diharapkan, diinginkan atau dipikirkankaryawan. Kepuasan kerja dapat diukur dari lima sub-variabel yaitu kepuasan karyawan terhadap gaji, kepuasan terhadap pekerjaan itu sendiri, kepuasan terhadap penyelia, kepuasan terhadap teman sekerja dan kepuasan terhadap promosi Schermerhorn (1991).

\section{Rekapitulasi Tingkat Kepuasan Karyawan}

Tingkat kepuasan karyawan di PT. Perkebunan Nusantara V Kebun Sei Rokan yang dijelaskan dalam variabel yang diukur berdasarkan gaji, pekerjaan itu sendiri, hubungan dengan penyelia, hubungan terhadap sesama rekan sekerja dan berdasarkan promosi yang dijelaskan pada Tabel 8 .

Tabel 8. Tingkat Kepuasan Karyawan

\begin{tabular}{llcl}
\hline No & Tingkat Kepuasan & Skor & Kategori \\
\hline 1 & Gaji & 4,19 & Sangat Puas \\
2 & Pekerjaan Itu Sendiri & 3,23 & Cukup Puas \\
3 & Penyelia & 3,76 & Puas \\
4 & Teman Sekerja & 3,69 & Puas \\
5 & Promosi & 3,43 & Puas \\
\hline & Rata-rata & $\mathbf{3 , 6 6}$ & Puas \\
\hline
\end{tabular}

Sumber: Data Olahan, 2015

8 | Analisis Kepuasan Kerja Karyawan Di PT Perkebunan Nusantara V Kebun Sei Rokan Kecamatan Pagarantapah Darussalam Kabupaten Rokan Hulu 
Tabel 8 menunjukkan bahwa tingkat kepuasan karyawan di PT Perkebunan Nusantara V Kebun Sei Rokan secara keseluruhan berada pada kategori "puas" dengan rata-rata skor 3,66. Artinya perusahaan sudah berhasil dalam mensejahterakan karyawannya meskipun belum mencapai ukuran maksimal. Hal ini menunjukkan bahwa karyawan puas akan semua variabel dalam penelitian. Berdasarkan seluruh variabel penelitian tentang tingkat kepuasan maka perolehan skor tertinggi ada pada tingkat kepuasan terhadap kepuasan dilihat dari gaji dengan kategori "sangat puas" dengan skor 4,19 variabel ini merupakan variabel yang perolehan skornya paling tinggi dari semua variabel tingkat kepuasan dalam penelitian ini. Artinya bahwa gaji yang di peroleh karyawan dari perusahaan sudah membuat karyawan sangat puas serta bonus yang di berikan karyawan membuat karyawan puas dan sistim penggajian dari perusahaan juga membuat karyawan sangat puas karna gaji karyawan diberikan dengan tepat waktu.Gaji merupakan hal terpenting yang harus diperhatikan bagi pihak pimpinan yang adadi perusahaan.Karyawan menerima gaji dari perusahaan berdasarkan golongan masing-masing karyawan dan khusus karyawan yang jenjang golongannya IA/00 disamakan dengan UMR yang berlaku di Provinsi riau.

Pada kategori pekerjaan itu sendiri dapat diketahui perolehan skor sebesar 3,23 dengan kategori "cukup puas". Berdasarkan pekerjaan karyawan merasa bahwa pekerjaan yang diberikan kepadanya sudah sesuai dengan bidang kemampuan karyawan. Perusahaan menetapkan dan memilih karyawan dalam pembagian kerja akan disesuaikan dengan keahlian dan kemampuan karyawan. Karyawan yang memiliki pekerjaan yang tidak seimbang dengan keahlian akan membuat motivasi dari diri karyawan akan semakin rendah. Motivasi juga mempengaruhi keinginan dan kepuasan karyawan dalam melakukan pekerjaan. Apabila suatu pekerjaan sesuai dengan keahlian karyawan maka karyawan tersebut pun akan semakin gigih dalam melakukan tugasnya dengan senang hati namun begitu juga sebaliknya apabila ada pekerjaan yang tidak sesuai dengan keahlian karyawan maka karyawan tersebut akan malas bekerja dan akan mogok kerja untuk beberapa hari. Perlu dipertimbangkan oleh para manager perusahaan untuk memperhatikan karyawan yang mogok kerja dan tingkat kehadirannya tinggi agar manager bisa mengevaluasi dan memotivasi karyawan untuk 
bekerja.Selain itu, aspek manajemen juga sangat penting untuk diterapkan lagi dalam perusahaan supaya semua visi dan misi perusahaan dapat terwujud dengan maksimal.

Sedangkan dalam kategori tingkat kepuasan dilihat dari penyelia dengan kategori "Puas" dengan nilai rata-rata 3,76 artinya bahwa penyelia atau pimpinan sudah berhasil membuat karyawan (bawahan) puas terhadap sikap dan keputusan dari pimpinan. Sifat dan karakter seorang pemimpin adalah mengayomi, ramah, melindungi, jujur, mengarahkan, mendidik dan bertanggung jawab sangat identik dengan gaya kepemimpinan dalam manajemen di sebuah perusahaan. Berdasarkan hasil wawancara yang peneliti lakukan, karyawan mengatakan bahwa mereka merasa puas terhadap pimpinan mereka. Hubungan atasan (penyelia) dengan bawahan (karyawan) perlu diperhatikan bahwa semakin dipererat agar terciptanya kesejahteran bagi karyawan karena akan mempengaruhi tingkat kepuasan dan motivasi karyawan juga untuk bekerja.

Pada kategori tingkat kepuasan karyawan terhadap promosi dalam kategori “ puas" dengan nilai rata-rata 3,43 hal ini harus dipertahankan oleh perusahaan karna karyawan puas terhadap jadwal promosi dan pelaksana promosi yang dilakukan perusahaan. Peningkatan karir (promosi) merupakan langkah awal bagi karyawan untuk bisa naik jabatan maupun golongan dari yang rendah ke tingkat yang lebih tinggi. Semua karyawan dapat mengikuti promosi atau peningkatan karir untuk naik golongan yang akan berpengaruh terhadap besarnya gaji yang diterima sesuai dengan prestasi kerja karyawan.

\section{KESIMPULAN DAN SARAN}

\section{Kesimpulan}

Berdasarkan hasil penelitian yang dilakukan dapat diambil kesimpulan sebagai berikut:

Karakteristik merupakan salah satu faktor internal yang mempengaruhi kepuasan bagi diri karyawan. Dari hasil penelitian diperoleh jumlah tenaga lakilaki lebih banyak yang bekerja yaitu sebesar 78 orang dengan persentase $86,66 \%$. Dari segi umur karyawan yang bekerja di perusahaan ini lebih banyak yang berumur 25-36 tahun sebanyak 39 orang 43,33\%. Tingkat pendidikan dalam penelitian ini lebih banyak karyawan memiliki tingkat pendidikan SMP yaitu 37 
orang $16,67 \%$. Dilihat dari lama bekerjanya antara 11-17 tahun lebih banyak yaitu 46 orang $51,11 \%$. Dilihat penghasilan yang diterima karyawan dapat diketahui bahwa > UMP yaitu 65 orang 72,22\%.

Dari hasil pengukuran skala likert yang dilakukan dalam penelitian ini di peroleh tingkat kepuasan karyawan dari faktor eksternal yaitu dari kepuasan terhadap gaji diperoleh dengan skor tertinggi yaitu 4,19 dengan kategori puas yang artinya karyawan puas terhadap gaji yang mereka terima. Sedangkan dilihat dari kepuasan terhadap pekerjaan itu sendiri diperoleh dengan skor terendah yaitu 3,23 dengan kategori cukup puas yang artinya karyawan seudah merasa cukup puas dengan pekerjaan mereka karena pekerjaan sudah sesuai dengan keahlian mereka dan mereka mampu menyelesaikan pekerjaan dengan baik.

\section{Saran}

Adapun saran yang dapat saya berikan dari hasil penelitian ini dilapangan adalah:

Sebaiknya perusahaan memikirkan alternatife yang akan dilakukan untuk meningkatkan kepuasan karyawan dalam bekerja agar terciptanya hubungan yang seimbang antara perusahaan dengan karyawan. Khususnya alternative dalam pencapaian kepuasan terhadap promosi bagi karyawan agar lebih dipertimbangkan kembali.

Penilaian hasil kerja yang dilakukan oleh perusahaan dalam hal ini yang dilakukan oleh supervisor hendaknya sesuai dengan kenyataan di lapangan dan sesuai dengan prosedur yang ditetapkan agar karyawan dapat memper kesempatan promosi yang sesuaidengan prestasi kerjanya.

\section{DAFTAR PUSTAKA}

Gomes, F. C. 1995. Manajemen Sumber Daya Manusia. Andi Offset. Yogyakarta.

Handoko, T. H. 2001. Manajemen Personalia dan Sumber Daya Manusia. BPFE Press.Yogyakarta.

Hasibuan,S.P.M.2009. Manajemen Sumber Daya Manusia. CV. Bumi Aksara. Jakarta.

Hasibuan, S.P. 2001. Produktivitas TenagaKerja di Indonesia. Jakarta.Rajawali

Lestari, A. I. 2008. Analisis Kepuasan Kerja Karyawan PT Perkebunan Nusantara VIII (Di Perkebunan CisalakBaru-Bantarjaya, Kabupaten 
Lebak) Skripsi. Program studi manajemen Agribisnis.Fakultas Pertanian. Institut Pertanian Bogor.

Schermerhorn Jr, dkk. 1991. Managing Organizational Behavior. New York.

Siagian, S. 1988. Proses Pengelolaan Pembangunan Nasional. CV Haji Masagung. Jakarta.

Sugyono. 2006. Metode Penelitian Bisnis. Salemba Empat. Jakarta. 